\title{
Investigation of stress in primates maintained in zoo and its main implications on behavior and well-being
}

Received: jan 2020; Accepted: set 2020

\author{
Maria Gabriella Conceição ${ }^{1^{*}}$, Sandra Maria Da Penha Conceição ${ }^{2}$
}

\begin{abstract}
Brazil is considered the country which holds the largest number of known primate species. At captives without environmental enrichment program, especially in zoos, it is common for the animals to be easily discouraged from captive life, being bound to develop chronic stress condition. This review aimed to provide veterinary professionals and students with updated bibliography on stress in zoo captive primates, focusing on reactions resulting from these changes, as well as their implications for behavior and well-being. Integrative literature review using descriptors "Captivity", "Stress", "Primates", "Zoos" and "Wellbeing", on the main scientific research bases. The present work highlighted stress responses and its consequences on primate's health and behavior captive in zoo through bibliographic survey, performing selected articles analysis, results interpretation, and discussion. It is concluded behavioral profile individual variations expose primates differently to stressful conditions. Public visitation, lack of structure, reduced enclosure, improper nutritional management, and unstimulated environment may be potential stress sources for some housed primates in zoo.

Keywords: Cortisol; Hypothalamic-pituitary-adrenal axis (EHA);
\end{abstract} Management; Environmental enrichment.

\section{Introduction}

Brazil is considered the country which holds the largest number of known primate species (AURICCHIO, 2017). Due to habitat destruction caused by deforestation, primates are apprehended daily and sent to several institutions such as CETAS (Wild Animal Screening Center), CRAS (Wild Animal Rehabilitation Center), and CETRAS (Wild Animal

\footnotetext{
${ }^{1}$ Centro Universitário das Faculdades Metropolitanas Unidas (FMU)

${ }^{2}$ Faculdade das Américas, FAM, Brasil

* Corresponding author. Endereço: Rua Ministro Nélson Hungria, 541 - Vila Tramontano, São Paulo

- SP, 05690-050. Telefone comercial: (11) 3132-3000 Email: mabriella99@gmail.com
} 
Treatment Center) throughout the country. Overpopulation in these establishments is often caused by the large number of seizures and the lack of structure and space to keep the animals for an extended period (SOUSA, 2014). The captivity which presents better conditions, and the possibility of animal welfare is the zoo, once the institutions mentioned above are overcrowded (SOUSA, 2014).

The Zoo can be defined as an establishment authorized by IBAMA, which houses several wild animals' species kept alive in captivity or in semifreedom. Its role is to replicate the natural environment, preserving the sheltered species habits. The animals are exposed to public visitation, as well as to serve scientific, conservationist, educational and socio-cultural purposes (IBAMA, 2008).

The Order of Primates represents a group of mammals, generally found in tropical regions of the planet, occupying the most varied types of habitats, from savannas to dense tropical forests (FORTES \& MARQUES, 2005). They are highly active animals in free life that usually spend a good part of their day looking for food and getting around. Due to such characteristics, the insertion of these animals in an ex-situ environment such as captivity may develop health and well-being problems, frequently related to chronic stress situation (COSTA \& PINTO, 2003), triggering high levels of stress and stereotyped behaviors (BERTOLI, 2017; POMERANTZ MEIRI \& TERKEL, 2013).

Several studies that address the physiology of stress emphasize the need for understanding of physiological mechanisms, mainly neurophysiology, once the response to stress in mammals is mediated via the sympathetic nervous system and the neuroendocrine system (DUARTE, 2016; MARGIS et al, 2003). The stress investigation in primates kept in zoo and its implications for behavior and well-being may be a useful element in forming environmental awareness programs aimed at captive environment improvements. Such measures must take account of health promotion of the 
animal welfare housed in captive zoo environment. In short, as primates are strongly affected by habitat fragmentation and found in large number in zoos, research evaluating the species' interactions with humans and its impacts on their behavior and well-being is necessary.

Therefore, the present review aimed to study the causes of stress in primates kept in zoos, focusing on the reactions resulting from these changes as well as their implications for behavior and well-being. It also identified some techniques which may be used to minimize the effects that the stressful condition may cause in confined primates.

\section{Material and methods}

The integrative review method was used to analyze the causes of stress in primates kept in zoos, focusing on the reactions resulting from these changes, as well as their implications for behavior and well-being. For the development of the proposed objective, bibliographic surveys were carried out on Google's academic base (https: //scholar.google.com.br), on the Scientific Electronic Library (SciELO) article storage base and on Virtual Library in Veterinary Medicine and Animal Science.

The research was based on studies by authors who addressed the physiology of stress, the effects of stress on captive primates' behavior and well-being, techniques used to minimize the effects of the stressful condition, environmental enrichment implanted in zoos as well as other studies relevant to the subject.

During selection process, it was chosen articles written in English, Portuguese, and Spanish, published over a period of more than 10 years. The online availability of articles also influenced the choice, once several articles were blocked for access. Subsequently, the most recent articles composed of the main criteria and keywords were evaluated. 
Based on the concepts presented by the authors, 26 articles were selected to carry out and develop this integrative review.

Table 1- Number of publications found in the information resources and included in the study. São Paulo, SP, Brazil, 2019.

\begin{tabular}{cccc}
\hline $\begin{array}{c}\text { Resource } \\
\text { Informational }\end{array}$ & Interface & $\begin{array}{c}\text { News } \\
\text { Found }\end{array}$ & Featured items \\
\hline SciELO & $\begin{array}{c}\text { SciELO - Scientific } \\
\text { Electronic Library } \\
\text { Online } \\
\text { Scielo.org }\end{array}$ & 6 & 3 \\
Google & Scholar.google.com & 39 & 20 \\
Academic & $\begin{array}{c}\text { Virtual Library in } \\
\text { Veterinary Medicine } \\
\text { and Animal Science } \\
\text { bvs-vet.org.br }\end{array}$ & 3 & 3 \\
\hline
\end{tabular}

Based on the inclusion and exclusion criteria, the number of articles found and included in the study was defined and data are shown in Table 1. Publications found in more than one source were added to the count only on the first interface on which they were found.

Therefore, from 48 articles found, 26 were included in the study, adding up to total of the 3 information resources used in this review.

Table 2- Characterization of the publications included in the study. São Paulo, SP, Brazil,

\begin{tabular}{|c|c|c|c|}
\hline Article & Authors & Year & Journal \\
\hline Introduction to primates & AURICCHIO, P. & 2017 & $\begin{array}{l}\text { Terra brasilis, p. 17-25. } \\
\text { Sao Paulo. }\end{array}$ \\
\hline $\begin{array}{l}\text { Environmental enrichment as a } \\
\text { stress reducer in capuchin monkeys } \\
\text { (cebus libidinosus) kept in a zoo }\end{array}$ & SOUSA, AB & 2014 & $\begin{array}{c}\text { Monograph- } \\
\text { Department of } \\
\text { biological sciences, } \\
\text { Paraíba. }\end{array}$ \\
\hline Ibama Normative Instruction & IBAMA & 2008 & IBAMA \\
\hline $\begin{array}{l}\text { Primate ecology and behavior: field } \\
\text { study methods. }\end{array}$ & $\begin{array}{l}\text { FORTES, VB; } \\
\text { BICCA- } \\
\text { MARQUES, JC }\end{array}$ & 2005 & Notebook La Salle XI \\
\hline Physiological and behavioral & BERTOLI, CP & 2017 & Dissertation - Institute \\
\hline
\end{tabular}


analysis of black lion tamarins in captivity: an assessment of the level of stress.

Socio-ecological factors correlate with levels of stereotypic behavior in zoo-housed primates

The different faces of animal behavior. Jundiaí

Relationship between stressors, stress, and anxiety

General adaptation syndrome and adaptation diseases.

Biological response to stress: implications for animal welfare

Pathophysiology of stress in captive wild animals and its implications for animal behavior and well-being literature review.

Response to stress: II. Resilience and vulnerability.

Environment, adaptation, and stress.

Endocrinology, reproduction, and lactation.

Treatise on medical physiology.

An introduction to behavioral endocrinology

Stress in Yucatan spider monkeys: effects of environmental conditions on fecal cortisol levels in wild and captive populations.

The use of glucocorticoid hormones or leucocyte profiles to measure stress in vertebrates: What's the difference?

Relation between the level of selfmutilation and the concentration of fecal metabolites of glucocorticoids

of Biosciences, Rio Claro.

POMERANTZ, O; MEIRI, S; TERKEL, J.

DEL-CLARO K, 2003 $\mathrm{PF}$

MARGIS, $R$ et al.

SEYLE, H.

MOBERG, GP 2000

ORSINI, H; BONDAN, EF

GALVÃO, C; SILVA, N. L; HÉLDERES P. A; SOUSA, MC KOSCINCZUK, 2014 $\mathrm{P}$

DICKSON, WM

HALL, JE; GUYTON, AC NELSON, RJ 2006 2005

RANGEL2009 NEGRÍN, A et al.

DAVIS, AK; MANEY, DL

PIZZUTTO, CS et al

2013

2003

1946

2015
Behavioral processes, v. 98, p. 85-91.

Brazilian Society of Ethology \& Livraria Conceito, p. 211-23.

Journal of Psychiatry of Rio Grande do Sul, v. 25 , n. 1 , p. 65-74.

Journal of Clinical Endocrinology, v. 6, p. 117-230.

The biology of animal stress: basic principles and implications for animal welfare, v. $1, \mathrm{p}$. 21.

2006 Inst. Magazine Health Science, v. 24, n. 1, p. 7 13.

Psychology Studies (Natal), v. 20, n. 2, p. 72-81.

Veterinary Magazine. 25. 67-76.

Physiology of domestic animals. 11th ed. Rio de Janeiro: Guanabara Koogan, p. 571-602. Elsevier Brasil.

Sinauer Associates.

Animal Conservation, 12, 496-502.

Methods in Ecology and Evolution, v. 9, n. 6, p. 1556-1568.

Research Vet. Bras., Rio de Janeiro, v. 35, n. 1, p. 62-66. 
inceptive chimpanzees (Pan troglodytes).

Evaluation of the impact of visitation on the behavior of two primate species: the howler monkey, 1940 and the capuchin monkey, 1792

Individual differences and response to visitors in zoo-housed Diana monkeys (Cercopithecus diana diana).

A note on the influence of visitors on the behavior and welfare of zoohoused gorillas.

Environmental enrichment in Brazilian zoos: in search of animal welfare.

The Visitor Effect on Zoo Animals: Implications and Opportunities for Zoo Animal Welfare

Effect of environmental enrichment in a group of mona araña (Ateles geoffroyi) in caution.

Guide to enriching the environmental conditions of captivity
GUIMARÃES, 2012 Municipal Zoo of JS
Canoas, Rio Grande do Sul - RS.

BARLOW, 2007

Catriona JC et al.

8th Annual Symposium on Zoo Research. P. 131.

WELLS, DL $2005 \quad$ Applied Animal Behavior Science, Vol. 93, n. 1-2, p. 13-17.

AZEVEDO, CS; 2018 FERREIRA, LB Revista Brasileira de Zoocências - Applied Ethology and Animal Welfare, v. 19 n. 2

SHERWEN, S. 2019 Animals, v. 9, n. 6, p. $\mathrm{L}$; 366.

HEMSWORTH, $\mathrm{PH}$

MARQUEZ-

2014 ARIAS, A. et al.

Salud Ment, Mexico, vol. 37 , n. 5 , p. $437-442$

Zoophilic Educational CELOTTI, ST $1997 \quad$ Society

\section{Results and discussion}

In Literature, the increase in stress is related to nutritional deficiency, absence of structure, reduction of enclosure, environment without stimuli, continuous presence of human beings, changes in grouping patterns and environmental factors such as temperature, humidity, light, among others (ESTEP \& DEWSBURY, 1996; RANGEL-NEGRÍN et al., 2009; BERTOLI, 2017).

Stress in the primate must be understood as physiological, neurohormonal process, which they undergo to face environmental change, as an attempt to adapt to the new conditions and, thus, maintain their homeostasis (FOWLER 2001). The discomfort condition itself generated by 
the environment, associated with the impossibility of escape, creates condition of intense stress for the primate (MENDONZA 1991).

\section{Stress}

Following the definition of stress, the individual's exposure to a particular stressor will cause several body changes, which will try to adapt to new conditions to maintain homeostasis (SEYLE, 1946; MOBERG, 2000; MARGIS et al., 2003; ORSINI \& BONDAN, 2006; GALVÃO-COELHO et al., 2015; FERREIRA, 2017; KOSCINCZUK, 2014). This process is defined as General Adaptation Syndrome (SGA), which is the set of responses triggered by a stressor and, according to Seyle (1946) and Moberg (2000), it can be divided into three stages: alarm or alert; resistance or adaptation; exhaustion or exhaustion.

Alarm or alert - the primate faces the stressor, and the balance is disrupted. In this process, activation of sympathetic autonomic nervous system occurs, which will cause the animals to be alert, causing cardiovascular changes such as elevated blood pressure, tachycardia, decreased blood circulation from peripheral regions to vital organs. Due to respiratory rate increase, there is greater oxygen availability; moreover, there is glucose release by the liver leading to increase the energy availability of muscles (DICKSON 1996; GALVÃO-COELHO et al., 2015; ORSINI, 2006).

Resistance or adaptation - the animal tries to get adapted to the stressor presence to restore homeostasis. Neurotransmitters had been released in several target organs, mainly in the adrenal medulla, because it will release catecholamines further reinforcing neural activation. The sympathetic autonomic nervous system goes into hyperactivity and there is 
intense stimulation of the neuroendocrine system for the release of cortisol, a steroid hormone synthesized and released by the adrenal glands cortex in response to hypothalamic-pituitary-adrenal axis (HPA) activation. Thus, glucocorticoids release promotes cellular actions for the synthesis of glucose, which is necessary to supply energy to the different tissues (GUYTON \& HALL, 2006; GALVÃO-COELHO et al 2015; ORSINI, 2006).

Exhaustion or Exhaustion - The last phase is characterized by the failure of animal's ability to adapt to the stressor. There is no rest, consequently no return to homeostasis. There is a chronic response of the animal's organism, and physiological and behavioral changes, leading to energy overload and system exhaustion (NELSON, 2005; GALVÃOCOELHO et al., 2015). Thereby, the physiological stress becomes pathological when the response intensity to the stressor remains for a long period, failing to search for homeostasis and altering the physiological and behavioral functions chronically.

\section{Factors that cause stress}

In recent years, there has been intensification of research and increase in demand for studies related to the assessment of the welfare of animals raised in captivity. According to Davis and Maney (2018), measuring stress in animals is essential in many ecological, zoological, and veterinary research environments. Measuring plasma levels of glucocorticoid hormones (hormones linked to stress) is one of methods. Many researchers carry out the analysis of faecal glucocorticoid metabolites (MFG) for the investigation and measurement of HPA axis reactivity and the cortisol level, due to the absence of animal immobilization as the daily collection of feces is part of the routine of animals raised in captivity (FERREIRA, 2015). 
Pizzutto (2015) has described the level of self-mutilation of chimpanzees in captivity and the concentration of fecal glucocorticoid metabolites (MFG) relationship, suggesting this injury may be associated with chronic stress condition of animals developed in captivity poor in stimuli. Such condition may cause changes in endocrine system, resulting in complications of the animal to adapt to the environment and consequently generating behavioral changes. In addition, the study indicates that the level of self-mutilation can be used as an indicator of chronic stress in chimpanzees.

Bertoli (2017) has demonstrated an experimental study carried out at the Primatology Center of Rio de Janeiro (CPRJ), where the MFG assessment and behavioral analysis of golden lion tamarins are performed. As a result, the study stated that individuals isolated in "individual cages" and individuals in the "dual male" treatment demonstrated less "typical" behaviors of species and higher abnormal behaviors levels due to the lack of movement possibility and social interaction, resulting in many stereotypes. Such author concluded that social isolation is one of the factors that can contribute to the compromise of well-being.

The study by Sousa (2014) described the capuchin monkeys (Sapajus Apella) behavior living in enclosures with different stress conditions and environmental stimuli and demonstrated results similar to Bertoli (2017). In this literature, capuchin monkeys kept in quarantine in the absence of environmental stimuli showed more stereotyped behaviors resulting from stress than the group maintained in semi-captive environments. Emphasizing that behaviors associated with stress are common in isolation. Additionally, Ferreira (2017) also described the existence of different behavioral profiles within the same population, which react differently to stress. The correlations of results and level of MFG analysis showed several stereotyped behaviors exhibited by the species against certain environmental conditions. Such study also concluded that more sociable 
animals are more resilient, both at the physiological and behavioral levels to the stresses of captivity.

Guimarães (2012) and Barlow et al. (2006) demonstrated the changes due to visitor's presence on the primate species behavior: Diana monkey (Cercopithecus diana diana) red howler monkey (Alouatta guariba) and capuchin monkey (Sapajus Apella) in zoos. Barlow et al. (2006) described that certain individuals of Diana monkey species are more likely to exhibit stress-indicative behavior (CIE) when visitor density is increased. Additionally, for part of individuals, it caused positive responses, showing significant increase in affiliative behavior, such as play.

On the other hand, Guimaraes (2012) described that ZMC howler monkeys at the Municipal Zoo of Canoas did not demonstrate any altered behavior or indicative of stress. However, in capuchin monkeys, intense locomotion behavior was observed, indicating stress caused by presence of visitors. The study suggests extending the resting time for these animals exposed to routine observation with measures to decrease the days and / or visiting hours.

Wells (2005) showed the gorillas behavior in zoo are also changed in visiting periods. The low density of visitors stimulated relaxation behavior, with gorillas spending most of their time resting. On the other hand, higher visitor's density encouraged significantly more intragroup aggressions, stereotypes, and auto grooming. These findings reinforce that gorillas, like many other primate species, have a low level of well-being and stereotyped behaviors due to the large number of visitors.

Recently, the study by Leal (2018) described a variance in influence level of public visitation on behavior of different types of primate species in zoo at the Jungle War Instruction Center in Manaus. It was indicated that visitors have influence in different ways at the individual level, which for some can be enriching, for others it can be a stress factor. One of the reasons reported would be the flow of visitation, once it is smaller when compared to 
larger zoos. Therefore, the study suggests another relevant point for the evaluation in future works, which is the inclusion of the visitation time during the behaviors, to verify the relationship between the behaviors of the primates, humans and the time spent in front of the enclosure.

\section{Animal welfare and animal enrichment}

Research confirms that animal's well-being is highly dependent on the interaction of the individual characteristics of each species with environmental factors. The enclosure can be considered an extreme environment for primates without the proper environmental enrichment. Breeding success depends on management and veterinary procedures that must rely on knowledge of primate behavioral needs. Environmental enrichment is the most used method in zoos to promote an increase in the level of well-being and a reduction in the levels of chronic stress. It is proven that this type of method improves the physical and psychological well-being of animals with the use of different activities, SHERWEN \& HEMSWORTH, 2019.

In Literature, the types of enrichments that have shown the greatest efficiency in raising the frequency of desirable primate behaviors are:

Physical enrichment - which includes changes in the size and shape of the enclosure.

Social enrichment - which focuses on modifying the individual's group that share the enclosure or have a direct or indirect relationship with other species.

Nutritional enrichment - which consists mainly of changing the way feeding is offered to animals, increasing the degree of difficulty in obtaining food. Peeled fruits, boxes with hidden food and insects are provided. 
There is also the introduction of new objects in the enclosure (forage panel, balls, seeds, roll, rattles, logs with holes, food in a stretch, bag, and boats) (UFAW, 1997; SILVA, 2019; MARQUEZ-ARIAS, 2014).

According to the cited works, it is possible to conclude that the visitor's presence and the lack of stimuli in captivity in zoo are the factors that most affect the animals' life quality. Strategic research and studies should be carried out with the purpose of targeting primates in search of improvements to ensure their increased life quality and avoiding the development of chronic stress.

\section{Conclusion}

Through the survey of works carried out, it was possible to arrive at three major themes which surround such research such as: chronic stress, impact of public visitation, environmental enrichment, and well-being. It is concluded that individual variations in the behavioral profile expose animals differently to stressful conditions. Public visitation, lack of structure, reduced enclosure, improper nutritional management, and unstimulated environment, may be potential stress sources for some housed primates in zoo. Different strategies to cope with stress must be developed for each species of captive primate in zoos, as an attempt to find and apply the best environmental enrichment project to help reducing the stress of primates of different species inserted in the zoo.

\section{Investigação do estresse em primatas mantidos em zoológicos e suas principais implicações no comportamento e bem-estar}

Resumo: O Brasil é considerado o país com maior número de espécies de primatas conhecidos. Em cativeiros que não possuem um programa de enriquecimento ambiental, é comum esses animais ficarem desestimulados 
facilmente com a vida cativa, principalmente em zoológicos, podendo desenvolver uma condição de estresse crônico. Esta revisão teve por objetivo contribuir para a promoção de maior bem-estar aos indivíduos que vivem em cativeiros e servir de auxílio para os profissionais e estudantes de veterinária com atualizações da bibliografia referente ao estresse em primatas cativos no zoológico, enfocando as reações decorrentes dessas alterações, bem como suas implicâncias no comportamento e bem-estar. Revisão integrativa da literatura utilizando os descritores "Cativeiro", "Estresse", "Primatas", "Zoológicos" e "Bem-Estar" nas principais bases de pesquisa cientifica. O presente trabalho obteve a identificação das respostas geradas pelo estresse e as suas consequências na saúde e no comportamento de primatas cativos em zoológicos por meio de levantamento bibliográfico, realizando a análise dos artigos selecionados na pesquisa, a interpretação e a discussão dos resultados obtidos. Concluise que variações individuais no perfil comportamental expõem os primatas de maneira diferente às condições estressoras. No zoológico, a visitação, a ausência de estrutura, a diminuição do recinto, o manejo nutricional incorreto e o ambiente sem estímulos, podem ser potenciais fontes de estresse para alguns primatas alojados.

Palavras-chave: Cortisol, Eixo hipotálamo-hipófise-adrenal (EHA), Manejo, Enriquecimento ambiental.

\section{References}

AURICCHIO, P. Introdução aos primatas, p. 17-25. Terra brasilis. São Paulo -SP, 2017.

AZEVEDO, Cristiano Schetini de; FERREIRA, Luciana Barçante. Enriquecimento ambiental em zoológicos brasileiros: em busca do bem-estar animal. 2018. https://doi.org/10.34019/2596-3325.2018.v19.24708

BARLOW, Catriona JC et al. Individual differences and response to visitors in zoohoused Diana monkeys (Cercopithecus diana diana). In: 8th Annual Symposium on Zoo Research. p. 131. 2007.

BERTOLI, Paula. C. Análise fisiológica e comportamental de micos-leões-pretos em cativeiro: uma avaliação do nível de estresse. 2017. Dissertação (Pós-graduação em Zoologia) - Instituto de biociências, Universidade Estadual Paulista, Rio Claro - SP, 2017. 
CELOTTI, S. Guia para o enriquecimento das condições ambientais de cativeiro. England: Universities Federation for Animal Welfare, 2001.

COSTA, M. J. R. P.; PINTO, A. A. Princípios de etologia aplicada ao bem-estar animal. Del-Claro K, Prezoto F. As distintas faces do comportamento animal. Jundiaí: SBEt-Sociedade Brasileira de Etologia \& Livraria Conceito, p. 211-23, 2003.

DAVIS, Andrew K.; MANEY, Donna L. The use of glucocorticoid hormones or leucocyte profiles to measure stress in vertebrates: What's the difference? Methods in Ecology and Evolution, v. 9, n. 6, p. 1556-1568, 2018. https://doi.org/10.1111/2041-210X.13020

DEL CLARO, Kleber; PREZOTO, Fábio; SABINO, José. As distintas faces do comportamento animal. CEP, v. 3278, p. 18, 2003.

DICKSON, W. M. Endocrinologia, reprodução e lactação. SWENSON, MJ; REECE, WO Dukes: fisiologia dos animais domésticos. $11^{\mathrm{a}}$ ed. Rio de Janeiro: Guanabara Koogan, p. 571-602, 1996.

DUARTE, Renata Bezerra. Efeito do estresse psicossocial sobre o comportamento alimentar de primatas não-humanos (Callithrix penicillata). 2016. viii, 114 f., il. Tese (Doutorado em Biologia Animal) - Universidade de Brasília, Brasília, 2016.

ESTEP, D.Q.; Dewsbury, D.A. Mammalian Reproductive behavior. In: KLEIMAN, D, et al. Wild Mammals in Captivity: Principles and Techniques. The University of Chicago Press (379-389), 1996.

FERREIRA, Vitor Hugo Bessa. Enfrentando o estresse: um estudo comportamental e fisiológico em macacos-prego (Sapajus libidinosus) cativos. 2017. 95f. Dissertação (Mestrado em Psicobiologia) - Centro de Biociências, Universidade Federal do Rio Grande do Norte, Natal, 2017. 
FORTES, Vanessa Barbisan; BICCA-MARQUES, Júlio César. Ecologia e comportamento de primatas: métodos de estudo de campo. Caderno La Salle XI, v. 2, n. 207-218, 2005.

FOWLER, Murray E. et al. Biology, medicine, and surgery of South American wild animals. Biology, Medicine, and Surgery of South American Wild Animals, 2001. https://doi.org/10.1002/9780470376980

GALVÃO-COELHO, Nicole Leite; SILVA, Hélderes Peregrino A; SOUSA, Maria q Cordeiro. Resposta ao estresse: II. Resiliência e vulnerabilidade. Estudos de Psicologia (Natal), v. 20, n. 2, p. 72-81, 2015. https://doi.org/10.5935/1678$\underline{4669.20150009}$

GUIMARÃES, Jéssica Schmidke. Avaliação do impacto da visitação sobre o comportamento de duas espécies de primatas: o bugio-ruivo Alouatta clamitans Cabrera, 1940 (Primates, Atelidae) e o macaco-prego Sapajus nigritus Kerr, 1792 [Hill, 1960] (Primates, Cebidae), no Zoológico Municipal de Canoas, Rio Grande do Sul - RS, 2012.

HALL, J. E. Mecanismos comportamentais e motivacionais do cérebro - o sistema límbico e o hipotálamo. In: HALL, J. E. Guyton \& Hall Tratado de Fisiologia Médica, $12^{\mathrm{a}}$ Ed. Rio de Janeiro,

Instrução Normativa Ibama 169/2008, de 20.fev.2008 Pág.1 de 14. Disponível em: <https://central3.to.gov.br/arquivo/201135/>. Acesso em: 2019-04-25.

KOSCINCZUK, P. Environment, adaptation, and stress. Revista Veterinaria. 25. 67-76. (2014). https://doi.org/10.30972/vet.251555

LEAL, Liliane Monteiro. Estudo do comportamento e do bem-estar de primatas cativos do zoológico do CIGS (Manaus, AM). 2018. 73 f. TCC (Graduação em Ciências Biológicas) - Universidade do Estado do Amazonas, Manaus, 2018. 
MARGIS, Regina et al. Relação entre estressores, estresse e ansiedade. Revista de Psiquiatria do Rio Grande do Sul, v. 25, n. 1, p. 65-74, 2003. https://doi.org/10.1590/S0101-81082003000400008

MARQUEZ-ARIAS, Alejandra et al. Efecto del enriquecimiento ambiental en un grupo de monos araña (Ateles geoffroyi) en cautiverio. Salud Ment, México, v. 37, n. 5, p. 437-442, oct. 2014. https://doi.org/10.17711/SM.0185-3325.2014.051

MENDOZA, S.P. Sociophysiology of well-being in nonhuman primates. Lab Anim Sci, Memphis, v.41, n.4, p.344-349, 1991.

MOBERG, Gary P. Biological response to stress: implications for animal welfare. The biology of animal stress: basic principles and implications for animal welfare, v. 1, p. 21, 2000. https://doi.org/10.1079/9780851993591.0001

NELSON, Randy J. An introduction to behavioral endocrinology. Sinauer Associates, 2005.

ORSINI, Heloísa; BONDAN, Eduardo Fernandes. Fisiopatologia do estresse em animais selvagens em cativeiro e suas implicações no comportamento e bem-estar animal-revisão da literatura. Revista Inst. Ciênc. Saúde, v. 24, n. 1, p. 7-13, 2006.

PIZZUTTO, Cristiane S. et al. Relation between the level of self-mutilation and the concentration of fecal metabolites of glucocorticoids inceptive chimpanzees (Pan troglodytes). Pesq. Vet. Bras., Rio de Janeiro, v. 35, n. 1, p. 62-66, Jan 2015. https://doi.org/10.1590/S0100-736X2015000100013

POMERANTZ, Ori; MEIRI, Shai; TERKEL, Joseph. Socio-ecological factors correlate with levels of stereotypic behavior in zoo-housed primates. Behavioural processes, v. 98, p. 85-91, 2013. https://doi.org/10.1016/j.beproc.2013.05.005

RANGEL-NEGRÍN, A et al. Stress in Yucatan spider monkeys: effects of environmental conditions on fecal cortisol levels in wild and captive populations. 
Animal Conservation, $12, \quad 496-502, \quad 2009 . \quad$ https://doi.org/10.1111/j.14691795.2009.00280.x

SEYLE, Hans. A síndrome geral da adaptação e as doenças da adaptação. Jornal da Endocrinologia Clínica, v. 6, p. 117-230, 1946.

SHERWEN, Sally L.; HEMSWORTH, Paul H. The Visitor Effect on Zoo Animals: Implications and Opportunities for Zoo Animal Welfare. Animals, v. 9, n. 6, p. 366, 2019. https://doi.org/10.3390/ani9060366

SILVA, R. G.; TRICHES, G.; BASSANI, M. Enriquecimento ambiental em zoológicos visando bem-estar animal, 2019.

SOUSA, Allana. B. Enriquecimento ambiental como redutor de estresse em macacos-prego (cebus libidinosus) mantidos em zoológico, 2014. Monografia (bacharelado em Ciências Biológicas) - Departamento de ciências biológicas, Universidade Federal da Paraíba, João Pessoa - PB, 2014.

UFAW - Universities Federation for Animal Welfare. Guia para o enriquecimento das condições ambientais do cativeiro (S. Celotti, Trad.). São Paulo: Sociedade Zoófila Educativa. 1997.

WELLS, Deborah L. A note on the influence of visitors on the behavior and welfare of zoo-housed gorillas. Applied Animal Behaviour Science, v. 93, n. 1-2, p. 13-17, 2005. https://doi.org/10.1016/j.applanim.2005.06.019 